\title{
Mercury bioaccumulation and the population dynamics of Mesopodopsis slabberi (Crustacea: Mysidacea) along a mercury contamination gradient
}

\author{
M. D'Ambrosio • S. C. Marques • U. M. Azeiteiro • \\ M. A. Pardal - E. Pereira - A. C. Duarte • \\ P. G. Cardoso
}

Accepted: 8 August 2013/Published online: 28 August 2013

(c) Springer Science+Business Media New York 2013

\begin{abstract}
The mercury bioaccumulation and population dynamics of the mysid Mesopodopsis slabberi was assessed along a mercury gradient in Ria de Aveiro (Portugal). M. slabberi is one of the most important mysid species in European temperate coastal shallow waters playing a key ecological role. Nevertheless, no references were found concerning the possible consequences of the $\mathrm{Hg}$ on the trophodynamics of these coastal ecosystems. M. slabberi showed a clear bioaccumulation along the $\mathrm{Hg}$ gradient and through life, with mature females reaching the highest concentrations. In terms of population structure, higher densities and biomasses of $M$. slabberi were assessed in the most contaminated areas contrarily to the least polluted areas. Despite the mercury accumulation in its tissues no strong negative effects on the structure and population dynamics of the species were observed. However, mysids might be important in the transfer of metals from the
\end{abstract}

\author{
M. D’Ambrosio · P. G. Cardoso ( $\varangle)$ \\ Institute of Marine Research (IMAR), Department of Life \\ Sciences, University of Coimbra, 3004-517 Coimbra, Portugal \\ e-mail: gcardoso@ci.uc.pt \\ S. C. Marques - M. A. Pardal \\ Centre for Functional Ecology (CFE), Department of Life \\ Sciences, University of Coimbra, PO Box 3046, \\ 3001-401 Coimbra, Portugal \\ U. M. Azeiteiro \\ Centre for Functional Ecology (CFE), Department of Sciences \\ and Technology, Universidade Aberta, 4200-055 Oporto, \\ Portugal \\ E. Pereira - A. C. Duarte \\ Centre for Environmental and Marine Studies (CESAM), \\ Department of Chemistry, University of Aveiro, \\ 3810-193 Aveiro, Portugal
}

sediments and zooplankton to higher trophic levels such as fishes, most of them with commercial interest.

Keywords Mercury contamination - Mysids · Mesopodopsis slabberi - Bioaccumulation .

Biomagnification · Population dynamics $\cdot$ Life span

\section{Introduction}

The deterioration of estuaries by the presence of metals and organometals results mainly from anthropogenic activities (Pereira et al. 2006). Due to their dangerous tendency to accumulate in aquatic organisms (Kennish 2002), these pollutants compromise the water quality and the health of biotic estuarine communities.

Mercury $(\mathrm{Hg})$ is a severe environmental contaminant due to its high mobility, persistence and lipophilicity (Coelho et al. 2007; Nunes et al. 2008). Mercury contamination can be a risk for the estuarine species, like many fishes which have commercial interest and, consequently, may have negative effects for human health.

Mysid shrimps (Crustacea: Mysidacea) are the most abundant taxonomic group of suprabenthic communities and are fundamental to the nursery function of coastal and estuarine ecosystems worldwide. The suprabenthos or hyperbenthos is the faunal element of the benthic boundary layer, corresponding to the animals living in the lowest strata of the water column and dependent on the proximity of the bottom (Fanelli et al. 2009 and references therein). They are omnivores, eating detritus, algae and different species of zooplankton, structuring the estuarine and coastal communities (Fockedey and Mees 1999). In water bodies, they play a very important role because they serve as a link between detritus and phyto- and zooplankton and 
are a food resource for many demersal and pelagic fish and larger epibenthic crustaceans (Cockcroft et al. 1988; Granda et al. 2004; Vilas et al. 2009).

One of the most abundant mysids in estuaries is the species Mesopodopsis slabberi. It is a marine species that can tolerate a great range of salinities (1.3-43) (Delgado et al. 1997) being able to enter in the estuaries (Vilas et al. 2009) and become abundant (Webb and Wooldridge 1990). Diel migratory movements are characteristic of $M$. slabberi grouping during daytime, in large swarms close to the substrate. At night it moves up into the water column (Remerie et al. 2006). For these reasons, M. slabberi may be considered a key species regulating trophic interactions in estuaries (Azeiteiro et al. 1999).

In the literature, there are few studies focusing on the effect of contaminants on mysid shrimps. For instance, Verslycke et al. (2003) examined the toxicity of metal mixtures in the estuarine mysid Neomysis integer under changing salinity. Lasenby and Van Duyn (1992) determined cadmium and zinc consumption and accumulation rates for immature and adult Mysis relicta feeding on sediments and zooplankton. Further, the effects of copper, cadmium and zinc were tested on Siriella armata (Pérez and Beiras 2010). However, none of them took into consideration the approach implemented in the present study. So far, this study is the only one that evaluates the impact of a contaminant (mercury) on the structure and population dynamics of an important mysid species (M. slabberi). The $\mathrm{Hg}$ bioaccumulation throughout its life cycle (juveniles, immature and mature females and males) was evaluated. Moreover, the effects of $\mathrm{Hg}$ on the population structure (density/biomass) and dynamics (reproduction and secondary production) of the species along an environmental $\mathrm{Hg}$ gradient was also assessed.

\section{Materials and methods}

Study site

The study was conducted in the Ria de Aveiro coastal lagoon, located on the northwest coast of Portugal $\left(40^{\circ} 38^{\prime} \mathrm{N}, 8^{\circ} 45^{\prime} \mathrm{W}\right)$ (Fig. 1). The Ria de Aveiro is formed by four branches, S. Jacinto-Ovar, Mira, Ilhavo and Espinheiro, and its topography consists of a complex web of islands and channels and a wide intertidal zones of mudflats and salt-marshes (Nunes et al. 2008; Pereira et al. 2009). Vouga and Antuã rivers are major contributors of freshwater runoff $(\approx 70 \%)$ to the Ria de Aveiro.

The Ria the Aveiro coastal lagoon has received, from 1950 until mid 1990s, continuous $\mathrm{Hg}$ discharges from a chlor-alkali plant located in Estarreja industrial complex.

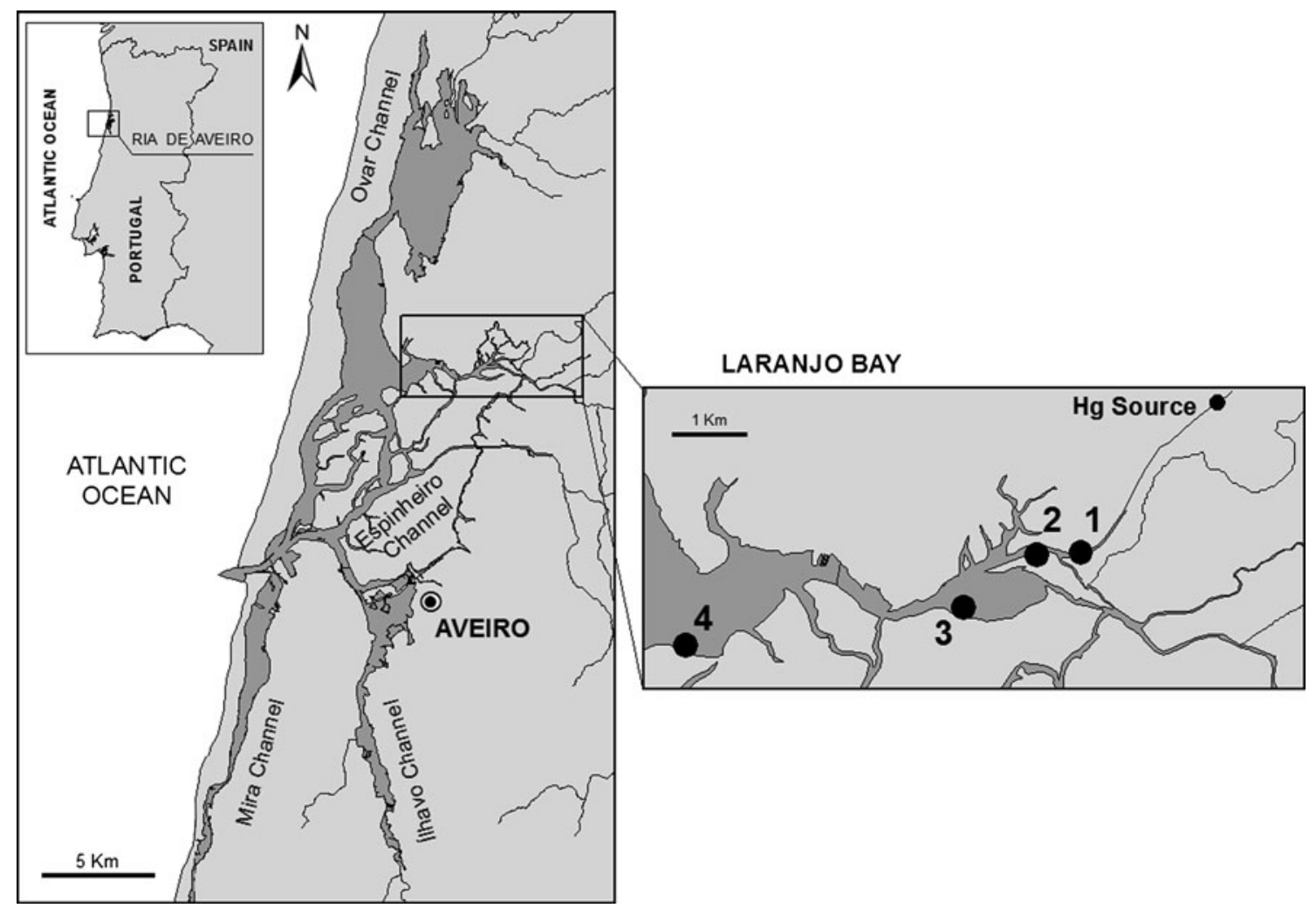

Fig. 1 Location of the sampling sites in Ria de Aveiro 
This has led to an environmental contamination gradient inside the lagoon (Coelho et al. 2007; Nunes et al. 2008; Pereira et al. 2009), mainly in the Laranjo Bay considered to be to a highly contaminated area located close to the mercury discharge source (Coelho et al. 2005). In the last decades, the $\mathrm{Hg}$ discharge decreased considerably due to legal restrictions which limit the discharge of mercury into fresh water down to $50 \mu \mathrm{g} \mathrm{Hg} \mathrm{L}^{-1}$ (Council Directive 82/176/EEC 1982). However, the Hg concentration in the sediments of some areas of the Ria is still high (Pereira et al. 2009).

Four sampling stations were selected in the Laranjo Bay along a transect defined by the distance from the mercury point source: station 1 was considered to be at the mercury point source in the lagoon, and the others stations are respectively $600 \mathrm{~m}$ (station 2), 3,000 $\mathrm{m}$ (station 3) and 5,000 m (station 4) (Fig. 1).

Field and sampling procedures

\section{Abiotic samples}

At each sampling station and occasion, in situ measurements of temperature, salinity, dissolved oxygen (DO) and $\mathrm{pH}$ of the water were taken. Also, water samples were collected with acid washed bottles for posterior determination of chlorophyll $a$, total suspended solids (TSS), total dissolved $\mathrm{Hg}$ and $\mathrm{Hg}$ associated to the suspended particulate matter (SPM). At the laboratory, water samples were filtered with $0.45 \mu \mathrm{m}$ pore size millipore filters and acidified with concentrated $\mathrm{HNO}_{3}$ "mercury free" to $\mathrm{pH}<2$ and maintained at $4{ }^{\circ} \mathrm{C}$ until analysis.

Sediments from each site were also collected for total mercury content quantification. They were homogenized and freeze-dried for posterior mercury analysis.

\section{Mercury quantifications in sediments, water column and organisms}

For total $\mathrm{Hg}$ quantification in organisms and sediments, freeze-dried samples were analyzed by thermal decomposition atomic absorption spectrometry with gold amalgamation, using a LECO AMA-254 (advanced mercury analyzer), with a limit of detection of $0.01 \mathrm{ng}$. Analytical quality control was performed using certified reference materials (CRMs), TORT-2 lobster hepatopancreas (for the organisms), while for the sediments; MESS-3 (low contaminated sediments) and PACS-2 (high contaminated sediments) were used. The values obtained for the whole CRM analysis ranged from 98 to $110 \%$ for the organisms and $97-103 \%$ (at 0.05 significance level) for the sediments. Analyses of CRMs and samples were always performed in triplicate and coefficient of variation was lower than $10 \%$.

Total dissolved $\mathrm{Hg}$ analysis was performed by coldvapour atomic fluorescence spectroscopy (CV-AFS), using a PS model Merlin 10.023 equipped with a detector PSA model 10.003 and using, as reducing agent, $\mathrm{SnCl}_{2}$. This analytical methodology is highly sensitive, allowing the measurement of $1 \mathrm{ng} \mathrm{L}^{-1}$ of mercury (Mucci et al. 1995).

For determination of $\mathrm{Hg}$ concentrations in SPM, filters (from the previous process of water filtration) were ovendried at $60^{\circ} \mathrm{C}$, digested with $\mathrm{HNO}_{3} 4 \mathrm{~mol} \mathrm{~L}{ }^{-1}$ and digests were analyzed by CV-AFS (Pato et al. 2008).

\section{Mesopodopsis slabberi samples}

The M. slabberi population was monitored monthly, during high tide over one year, from November 2010 to November 2011. The samples were collected during the day, at flood tide, by means of a modified suprabenthic sledge, consisting of a heavy metal frame with a rectangular $50 \mathrm{~cm}$ high $\times 40 \mathrm{~cm}$ wide opening equipped with a $500 \mu \mathrm{m}$ mesh net. The sledge samples the water column between 1 and $50 \mathrm{~cm}$ above the bottom, and was trawled at ca. 1.5 knots for about $1.5 \mathrm{~min}$ to avoid the clogging during the tows. The volume of water filtered was estimated by a HydroBios flow meter fixed in the opening of the net and the average filtered volume was $19 \mathrm{~m}^{3}$.

The collected specimens for $\mathrm{Hg}$ quantification were immediately transferred to a cool box and transported to the laboratory where they were sorted, frozen and afterwards freeze-dried for posterior analysis. The remaining individuals (for population dynamics study) were fixed with $4 \%$ buffered formalin. Later, organisms were separated under dissecting microscope and transferred to $70 \%$ ethanol. Individuals of $M$. slabberi were counted and classified into five categories: (1) juveniles, in which sexual characteristics were absent; (2) immature males and (3) immature females, in which sexual characteristics were not fully developed; (4) mature males and (5) mature females, in which sexual characteristics were completely developed. Total body length (TL) (mm) was estimated using the formula: $\mathrm{TL}=2.5 \times \mathrm{CL}+0.012$, calculated by Azeiteiro et al. (1999). Carapace length (CL) (mm) of each organism was measured from anterior tip to posterior tip of the rostrum (Azeiteiro et al. 1999) being afterwards all individuals ranged in 24 different size classes. For the $\mathrm{Hg}$ bioaccumulation analysis, the size classes were grouped into 3 different size classes.

For biomass quantification, individuals were dried at $60{ }^{\circ} \mathrm{C}$ for $72 \mathrm{~h}$ and weighed (to the nearest $0.01 \mathrm{mg}$ ) with a microbalance. The ash free dry weight (AFDW) (mg) was assessed after combustion of the organisms for $8 \mathrm{~h}$ at $450{ }^{\circ} \mathrm{C}$. 
Growth rates of $M$. slabberi were estimated by tracking recognizable cohorts in size frequency distributions over successive sample dates using FAO-ICLARM Stock Assessment Tool package (FISAT II software) (Gayanilo and Pauly 1997). For this analysis the data from the four sampling stations was pooled together, since in some of them the number of individuals was very low.

Annual net production estimates $(P)$ based on cohort recognition were estimated, as described in Dauvin (1986). Total values of $P$ for the population as:

$P=\sum_{n=1}^{N} P_{\mathrm{c} n}$

where $\mathrm{P}_{\mathrm{cn}}$ is the growth production of cohort $n . \bar{B}$, the annual mean population biomass, is calculated as

$\bar{B}=(1 / \mathrm{T}) \sum_{n=1}^{N} \bar{B}_{n \mathrm{t}}$

where $\mathrm{T}$ is the period of study, $N$ is the number of successive cohorts in the period T, $\bar{B}_{n t}$ is the mean biomass of cohort $n$; and $\mathrm{t}$ is the duration of the cohort $n$ (Cardoso et al. 2005).

\section{Statistical analysis}

Differences among sampling stations for total mercury (in water and sediment), dissolved $\mathrm{Hg}$ and SPM were assessed using 1-way-ANOVAs. All data were previously checked for normality and homogeneity of variances (Zar 1996). When criteria were not met, data was transformed appropriately and checked again for normality and homocedasticity. When after data transformation criteria were still not met, non-parametric tests were applied (Kruskal-Wallis test).

For the organisms, two-factor ANOVA (sites $\times$ size classes) was carried out followed by a multiple comparison test, the Unequal N HSD test, if significant, in order to determine differences in mercury bioaccumulated between size classes of different individual groups at different sites. All data were previously checked for normality and homocedasticity as explained previously.

\section{Results}

Physicochemical parameters of the water column

Temperature, salinity and chlorophyll $a$ values showed a typical seasonal variation, recording lower values during the winter and higher values during the summer (Fig. 2a-c). An opposite pattern for the dissolved oxygen was observed with
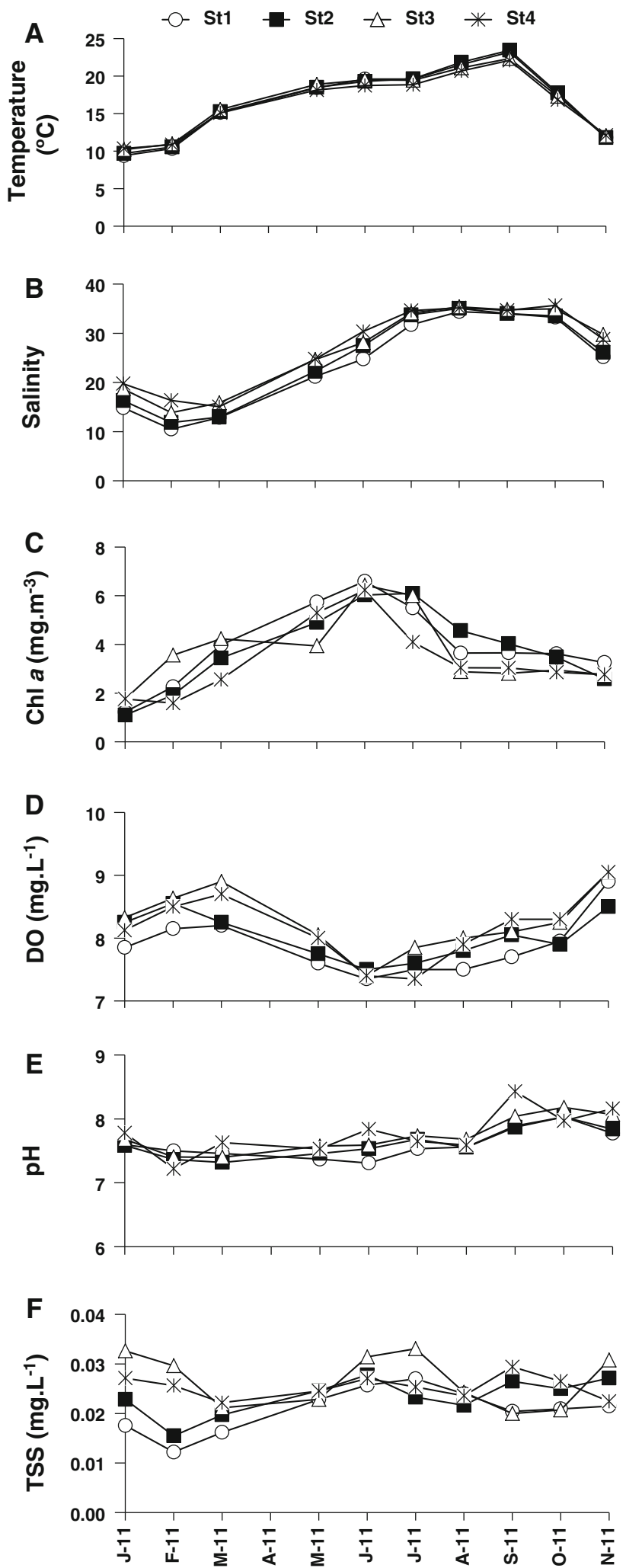

Fig. 2 Environmental parameters of the water. a Temperature; b salinity; c chlorophyll $a$; d dissolved oxygen; e $\mathrm{pH}$; f total suspended solids in the four sampling stations 
higher values during winter and lower ones during summer (Fig. 2d). Concerning pH, values were relatively constant all over the study period at all sampling stations (Fig. 2e). The total suspended solids showed an irregular pattern (Fig. 2f). No significant differences were observed between the four sampling stations for all the environmental variables measured (1-way-ANOVA, Temperature: $\mathrm{F}_{3}=0.01, P>0.05$; Oxygen: $\quad \mathrm{F}_{3}=0.62, \quad P>0.05 ; \quad$ Salinity: $\quad \mathrm{F}_{3}=0.25$, $P>0.05 ; \quad \mathrm{pH}: \mathrm{F}_{3}=0.62, \quad P>0.05 ;$ Chlorophyll $a$ : $\mathrm{F}_{3}=0.18, P>0.05$; TSS: $\left.\mathrm{F}_{3}=2.15, P>0.05\right)$.

Mercury concentrations in sediments and water column

Mercury concentrations in sediments, water and SPM are shown in Fig. 3. Total $\mathrm{Hg}$ in sediments showed a clear spatial gradient. Station 1 had the highest mercury concentration while station 4 had the lowest. In general, highest values were recorded during spring and lowest during winter and summer (1-way-ANOVA, $\mathrm{F}_{3}=167.8$, $P<0.05)$ (Fig. 3a).

Total dissolved Hg presented lower values during winter and spring and higher concentrations were recorded during the summer and autumn (Fig. 3b). Spatially, station 1 registered higher dissolved $\mathrm{Hg}$ concentrations than the other three stations, being local 4 the one that registered the lowest $\mathrm{Hg}$ concentrations. No significant differences were observed between sampling stations (Kruskal-Wallis, $\mathrm{H}_{3}=0.87, P>0.05$ ).

In the SPM fraction, we may consider the existence of a $\mathrm{Hg}$ gradient especially during summer and autumn (Fig. 3c). Significant differences were observed between stations 1 and 3, stations 1 and 4 and stations 2 and 4 (1way-ANOVA, $\left.\mathrm{F}_{3}=6.58, P<0.05\right)$.

\section{Mercury bioaccumulation in Mesopodopsis slabberi}

The results indicated a clear $\mathrm{Hg}$ bioaccumulation throughout the spatial gradient, with higher values at stations 1 and 2 (Fig. 4a, b) and lower values at stations 3 and 4 (Fig. 4c, d). Significant differences between sampling stations (2-way ANOVA, $\left.\mathrm{F}_{3}=9.74, P<0.05\right)$ were observed for the extreme contamination conditions (St $1 \neq \mathrm{St} 4$ and St $\neq \mathrm{St} 4)$, while the two most contaminated areas did not show significant differences between them. Moreover, a clear accumulation was observed throughout the mysids' life span with significant differences between age classes (2-way-ANOVA, $\mathrm{F}_{7}=26.78, P<0.05$ ). The juveniles (both class sizes: 1.1-1.7 and 1.7-2.3) always presented significant lower $\mathrm{Hg}$ concentrations than the other categories (2-way-ANOVA, $P<0.05)$. Also, immature females and males were significantly different from the mature ones $(P<0.05)$ being the mature females the ones that significantly accumulated more mercury. A significant interaction between size classes and
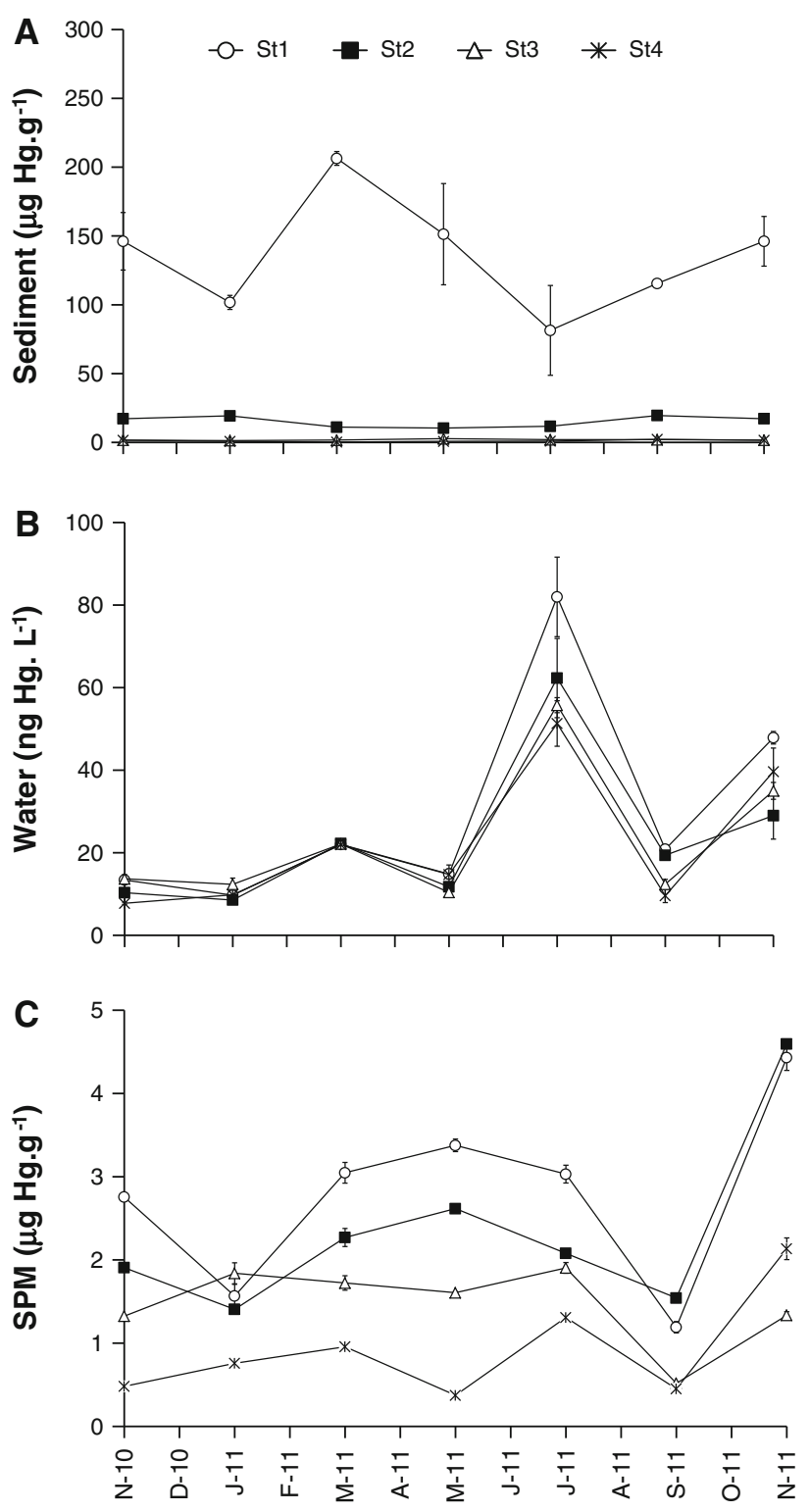

Fig. 3 a Total $\mathrm{Hg}$ in the sediment; $\mathbf{b}$ total dissolved $\mathrm{Hg}$ in the water; c $\mathrm{Hg}$ in the SPM at the four sampling stations

sites was observed probably because there were differences in the size classes between the extreme areas ( $\mathrm{St} 1$ and $\mathrm{St} 2 \neq \mathrm{St} 4)$ while in the closest stations there were no differences $(\mathrm{St} 1=\mathrm{St} 2$ and $\mathrm{St} 3=\mathrm{St} 4)$.

Spatial distribution and population structure of Mesopodopsis slabberi

Mesopodopsis slabberi population densities varied considerably along the $\mathrm{Hg}$ gradient. The highest population densities were found, generally, in the upstream section of the Laranjo Bay peaking, during the summer, at station 1 and, during the autumn, at stations 2 and 3 (Fig. 5a). The population densities recorded at station 4 were consistently 

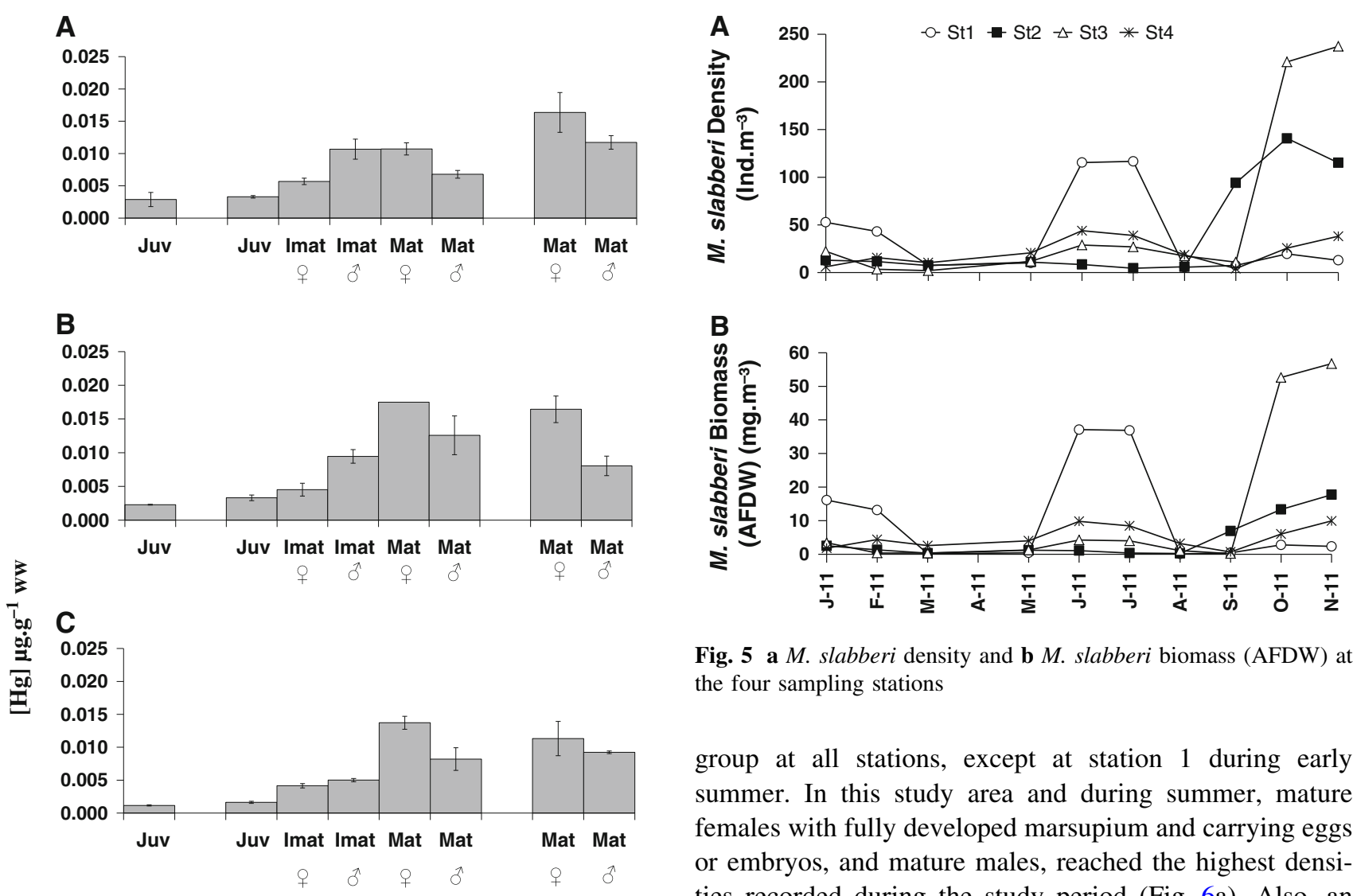

Fig. 5 a $M$. slabberi density and $\mathbf{b}$ M. slabberi biomass (AFDW) at the four sampling stations

group at all stations, except at station 1 during early summer. In this study area and during summer, mature females with fully developed marsupium and carrying eggs or embryos, and mature males, reached the highest densities recorded during the study period (Fig. 6a). Also, an increase of juveniles, immature males and females' densities was observed. At station 2 a substantial peak of juveniles as well as a slight increase of the immature males and females' densities was observed during autumn/winter (Fig. 6b). At station 3 an increase of juveniles' densities during summer was recorded and in the late summer/ autumn a substantial increase in the density of immature males and females, and mature females was observed (Fig. 6c). Mature males were always represented in low densities. At station 4 (Fig. 6d) all the studied stages were present in lower densities, except for the juveniles which were concentrated in July and August. The sex ratios showed that during most of the study period and for most of the sampling stations the females were dominant (mainly at stations 1 and 2), except in the late summer, mainly at station 4, where the situation was reversed (Fig. 6e).

the lowest ones, showing a slight increase only during the summer and in November 2011. Low densities were observed in March and August at all the stations.

In order to relate biomass and total length, a data set of 193 individuals measured and weighed throughout the study was used to provide a single regression equation $\left(\right.$ AFDW $\left.=0.057 \mathrm{TL}^{2.5552}, N=193, \mathrm{R}^{2}=0.9115\right)$. The biomass values shown in Fig. $5 \mathrm{~b}$ reflected, basically, the same pattern of the densities.

Mesopodopsis slabberi population was sexually active throughout the year, the juveniles being the most abundant

Growth and life span

Size-frequency polymodal distributions were analyzed for recognizable cohorts (Fig. 7). Considering that in some study areas the number of individuals was very low it was decided to perform the analysis pooling together the information of the four stations. It was possible to recognize four cohorts with two strong recruitments in July and 
A

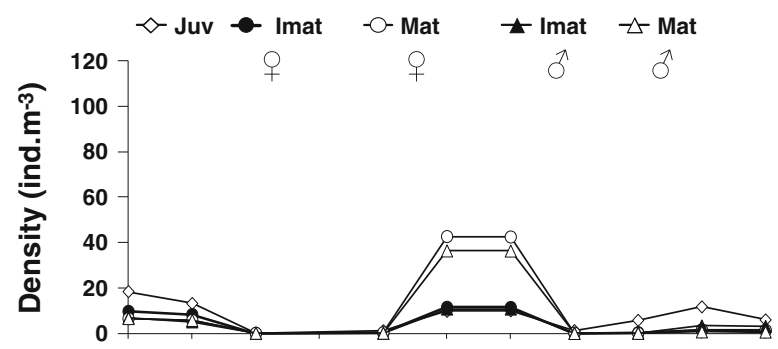

B

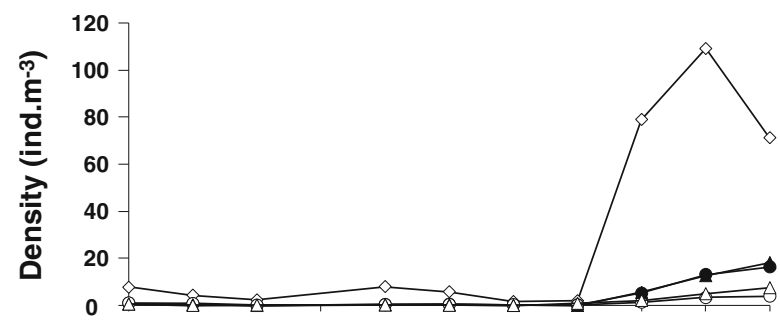

C

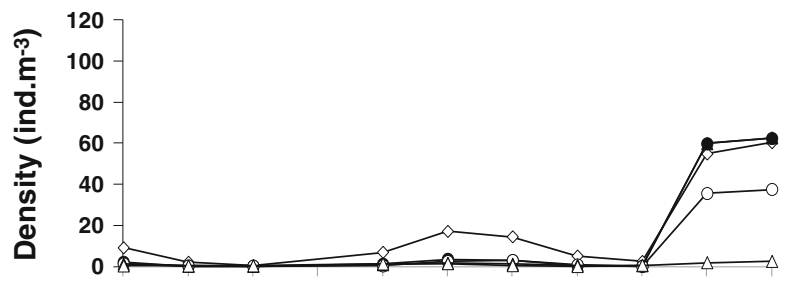

D

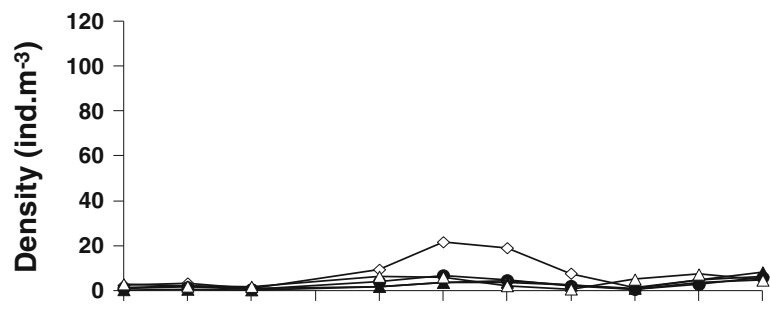

E

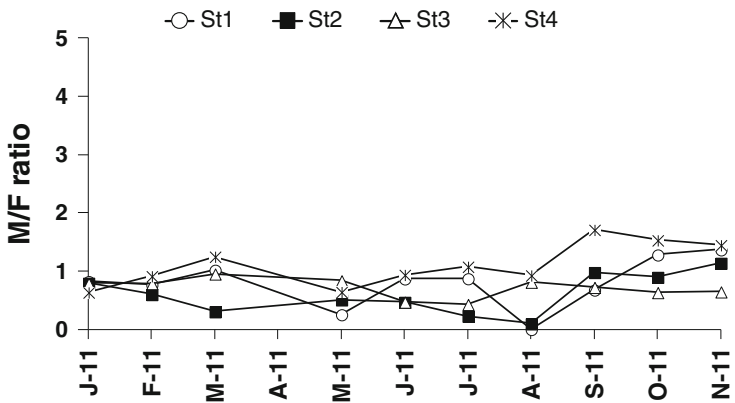

Fig. 6 Distribution of juveniles, immature males, immature females, mature males and mature females of $M$. slabberi in a station 1; b station 2; c station 3; d station 4, e males/females ratio at the four sampling stations

September. Therefore, all the organisms represented in January and May belonged to the two oldest cohorts, C1 and $\mathrm{C} 2$. Cohorts of $\mathrm{C} 2$ and $\mathrm{C} 3$ were dominant and in October the cohorts of the juveniles were $\mathrm{C} 3$ and $\mathrm{C} 4$. Based on the cohorts' information, the lifespan of M. slabberi was estimated in $11 \pm 1$ months (Fig. 8).
January 2011

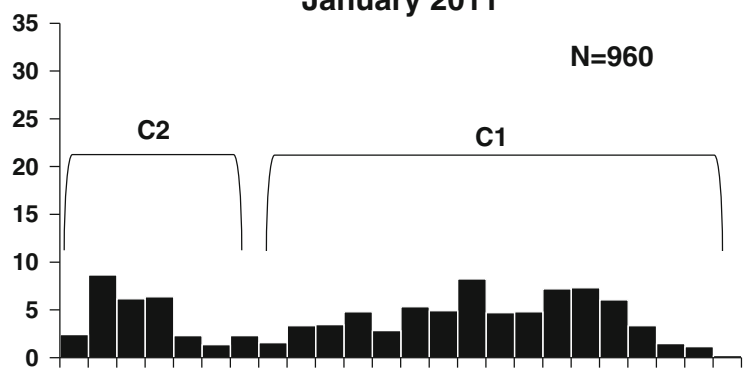

May 2011

$\mathrm{N}=794$

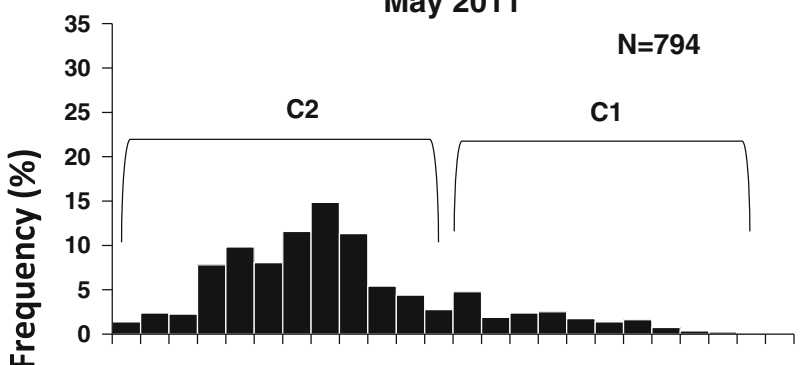

$\mathrm{N}=506$

C3

July 2011

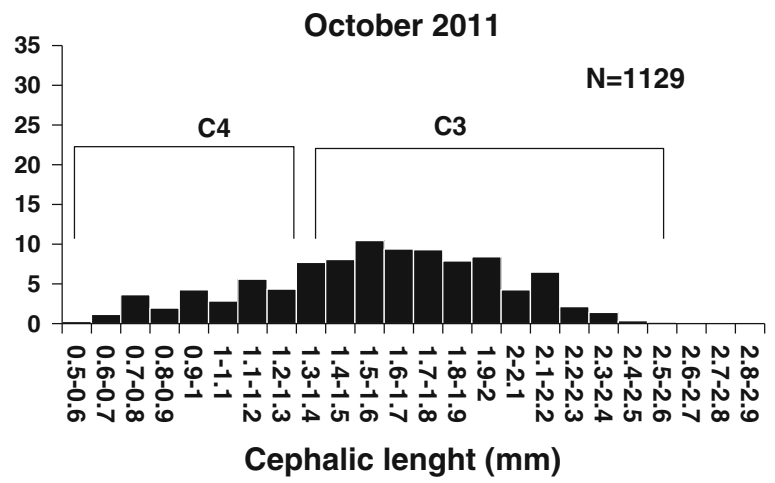

Fig. 7 Size frequency distribution for the total M. slabberi population. The 4 cohorts (C) are represented and the number $(N)$ of individuals found in each month is shown

Through the analysis of the densities of the several age groups (juveniles, immature and mature individuals) at the four sampling stations and through the cohorts study, it is possible to resume the life cycle of M. slabberi population, as illustrated in Fig. 9. Therefore, the main recruitment phases were detected during the summer, when the mature males and females at station 1 generated two new cohorts that appeared in July and September. During the summer, the juveniles moved, especially from the station 1 to the stations 2 and 3. A non-significant 
number of juveniles was recorded at station 4 . Then, the juveniles passed to the immature phase and swam upstream from station 4 to station 3 and, during the autumn, to station 2. During the winter passed from station 2 , where the immature stages were more abundant, to station 1. Finally, in the following spring the immature males and females passed to the mature stage to restart this annual cycle.

\section{Growth productivity}

Growth production $(P)$ and mean population biomass $(\bar{B})$ values of $M$. slabberi population are shown in Table 1 . The highest $P$ and $\bar{B}$ values were recorded at stations 1 and 3 . At station 3 the values were strongly influenced by the huge density values recorded in October 2011. The $P / \bar{B}$ ratios were similar at all the stations.

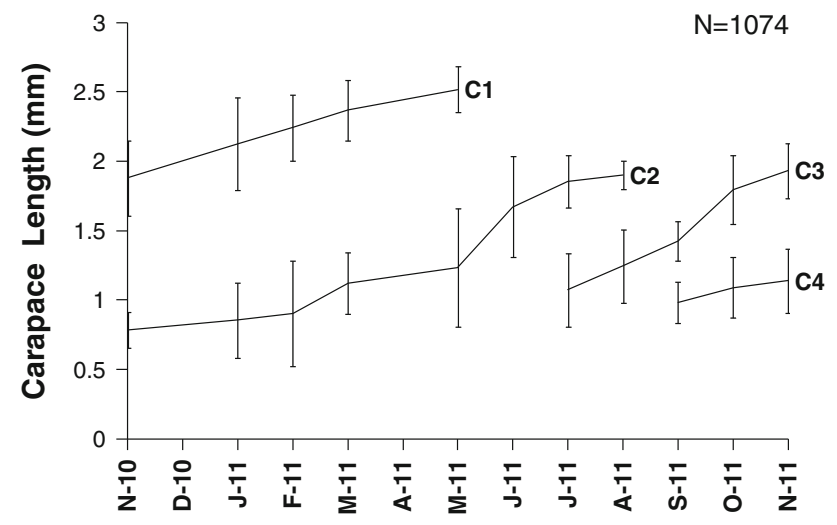

Fig. 8 Estimated growth (field growth data) of cohorts $(C) \pm$ standard deviation. $N=$ number of individuals used for the analyses

\section{Discussion}

The results of the present work showed a clear Hg bioaccumulation by the M. slabberi organisms according to the spatial gradient, which is reflected by the $\mathrm{Hg}$ concentrations in the water column and in the surface sediments, presenting actually much higher values than pre-industrial levels (0.05 $\mathrm{gg} \mathrm{g}^{-1}$; Laane 1992).

The $\mathrm{Hg}$ accumulation occurs, certainly, through the trophic chain, because $\mathrm{Hg}$ accumulates in phytoplankton by passive diffusion across the membrane (Mason et al. 1995) and M. slabberi population consumes an important portion of phytoplankton produced daily (Cockcroft et al. 1988). According to the bioaccumulation process, juveniles presented, for all the stations, the lowest $\mathrm{Hg}$ concentrations while mature females presented the highest ones. This result indicates that there is $\mathrm{Hg}$ accumulation through life, especially in the females, probably due to the presence of more lipid contents associated to fully developed marsupium carrying eggs or embryos. Despite in the present work the concentrations of methyl mercury (lipophilic compound) were not evaluated, it is likely that the percentage of organic mercury would also be higher in

Table 1 Estimation of the production for M. slabberi at the four sampling stations

\begin{tabular}{llrl}
\hline & $\begin{array}{l}P(\mathrm{mg} \mathrm{AFDW} \\
\left.\mathrm{m}^{-3} \text { year }^{-1}\right)\end{array}$ & $\bar{B}\left(\mathrm{mg} \mathrm{AFDW} \mathrm{m}{ }^{-3}\right)$ & $P / \bar{B}$ \\
\hline St1 & 32.83 & 8.34 & 3.94 \\
St2 & 12.59 & 3.94 & 3.20 \\
St3 & 39.19 & 10.96 & 3.58 \\
St4 & 17.94 & 4.43 & 4.05 \\
\hline
\end{tabular}

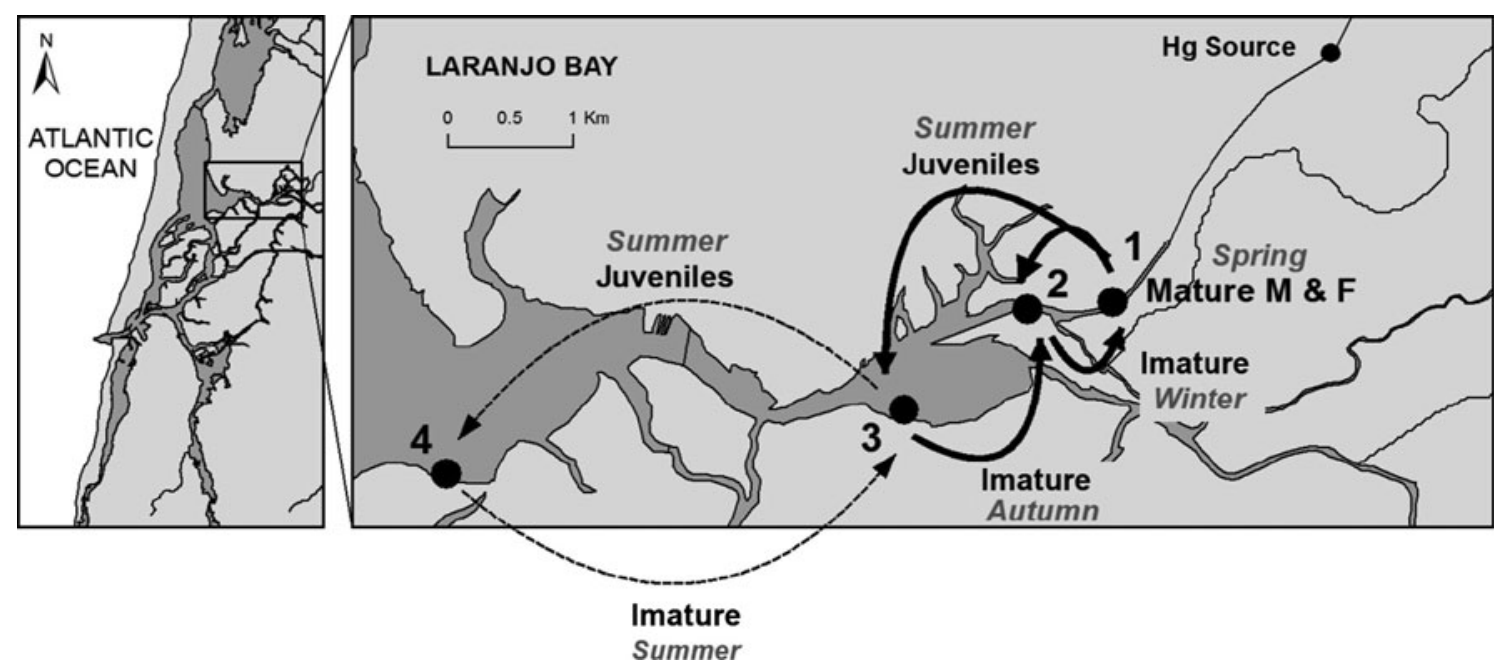

Fig. 9 Schematic representation of the annual life cycle of M. slabberi in the Laranjo bay 
females, which explains the present results. Our observations are in agreement with other studies with aquatic invertebrates which revealed a trend of increasing $\mathrm{Hg}$ concentrations with age (Coelho et al. 2006; Elahi et al. 2012 and references therein). In addition, gender differences in the $\mathrm{Hg}$ tissue concentrations have also been reported in some fish and invertebrate species. Other explanations for the differences in accumulation between the genders have been mainly attributed to differences in diet, or due to differences in habitat (Elahi et al. 2012 and references therein). Our results are in agreement with those of Bu-Olayan et al. (1998), who investigated the relationship between $\mathrm{Hg}$ level with total length, total weight and sex in Thenus orientalis (decapod) from the Persian Gulf. Also, in this study $\mathrm{Hg}$ concentrations in $T$. orientalis females were higher than in males. Also, for the red shrimp (Aristeus antennatus), a significant correlation was found between weight and carapace length with $\mathrm{Hg}$ concentration, while total $\mathrm{Hg}$ in females was higher than males (Drava et al. 2004).

Mesopodopsis slabberi revealed to be one of the most abundant suprabenthic species in Ria de Aveiro, both in terms of density and biomass. Generally, the highest density and biomass values were recorded at all the sampling stations, especially at station 1, during the summer, probably due to an active immigration from the adjacent areas for reproduction. Gentile et al. (1982) described a direct relationship between increased temperature (in the $19-25{ }^{\circ} \mathrm{C}$ range) and the number of young produced. In the present study mature males and females, at station 1 , generated two new cohorts that appeared in July and September, when the highest water temperatures were recorded.

The decline in density and biomass values attained during winter, particularly at station 2, station 3 and station 4 , was possibly due to natural mortality and emigration towards downstream areas of the system where temperature and salinity are more favorable. Seasonal variation in salinity preferences of M. slabberi has been described. For example, Azeiteiro et al. (1999) described migrations of $M$. slabberi from the Mondego estuary to neritic waters in January, perhaps due to low salinity in estuaries and in August, probably due to lower oxygen levels and higher temperatures. In the Westerschelde estuary (SW Netherlands) Rappé et al. (2011) described a winter minimum in M. slabberi abundance like a possible combination of natural mortality and active emigration to neritic waters and a summer/autumn maximum in M. slabberi abundance in the estuary due to the combined effect of active immigration and reproduction. Another explanation proposed by González-Ortegón and Drake (2012) defends that winter freshwater runoff brings high inorganic matter content that can had a negative effect on the density of M. slabberi by leading to an increased detritivory/herbivory ratio (Neomysis integer/M. slabberi ratio).

The most abundant group at all stations throughout the whole sampling period were the juveniles, except at station 1 during the summer. This means that the reproduction of M. slabberi population was continuous, as already demonstrated in Azeiteiro et al. (1999). Also, Delgado et al. (1997), in the Ebro delta observed a similar pattern of reproduction throughout the year for this mysid species.

Contrarily to the results of Azeiteiro et al. (1999) that failed to identify cohorts, growth rates and life expectancy for M. slabberi in the Mondego estuary, in the present study a total of four cohorts, with two strong recruitments per year (in july and september) were identified. The life span of M. slabberi was estimated in $11 \pm 1$ months. This life expectancy was higher than the one estimated by Delgado et al. (1997) for the same species (7-8 months) in the Ebro delta. Considering that the Ebro delta has a mediterranean influence, with higher water temperatures than the Ria de Aveiro it is expected that growth rates would be greater and consequently life spans tends to be shorter.

Concerning growth production, there is a complete worldwide lack of information on this parameter for this kind of organisms. By comparing the present results (Table 1) with those obtained by Azeiteiro et al. (1999) and despite the different methodology used (empiric methodology) $\left(P=16.02 \mathrm{mg} \mathrm{m}^{-3}\right.$ year $\left.^{-1}\right)$, we realize that our values were slightly higher. This indicates that despite the mercury contamination, the Ria de Aveiro, namely the Laranjo Bay is still a very productive system.

Regardless of the mercury accumulation by the species, this was not sufficient to negatively affect the population dynamics, the productivity and the life cycle of $M$. slabberi population. Contrarily to these results, in the same system, were recently observed negative effects of mercury on the growth and life span of the small gastropod, Peringia ulvae (Cardoso et al. 2013). To our knowledge, there is a great lack of information about the effects of mercury on the population dynamics of marine species. Most of the literature is focused mainly on $\mathrm{Hg}$ levels accumulated by species, according to age, length and gender (Minganti et al. 1996; Coelho et al. 2006; Elahi et al. 2012).

Concerning the non-ecotoxicological effects observed in the mysids, it may be related to the fact that despite the maximum $\mathrm{Hg}$ concentrations recorded in the water column (during summer/autumn) were above the EAC (Ecotoxicological Assessment Criteria) (OSPAR Convention; Bignert et al. 2004) threshold ( $>51 \mathrm{ng} \mathrm{L}^{-1}$ ) and the MACEQS (maximum acceptable concentrations-environmental quality standards) (according the WFD) limit $\left(70 \mathrm{ng} \mathrm{L}^{-1}\right)$ they seem insignificant to cause major damages on the 
structure and functioning of the species. This result is corroborated by a work developed by Gentile et al. (1982) in which were only observed effects on survival and reproductive success of mysids with cadmium concentrations higher than $10.0 \mu \mathrm{g} \mathrm{L}^{-1}$. Another work from Roast et al. (2000), revealed that the swimming behavior of the mysid Neomysis integer was disrupted at cadmium concentrations of $0.5 \mu \mathrm{g} \mathrm{L}^{-1}$, a significantly lower cadmium concentration than that causing mortality (7 day LC50 of $\left.2.58 \mu \mathrm{g} \mathrm{Cd}(\mathrm{aq})^{2+} \mathrm{L}^{-1}\right)$.

Besides all the results discussed, this work is also important because it allowed a better understanding of the life cycle of the M. slabberi population and its spatial distribution, which had not yet been described in previous studies. Considering the important ecological role in estuaries of M. slabberi and, in general, of mysid shrimps, several studies were carried out about its diel horizontal migrations (Webb and Wooldridge 1990), its spatial distribution (Vilas et al. 2009; Rappé et al. 2011), and the potential role of these organisms for ecological research (Sardo et al. 2005).

Studies like this one, concerning the bioaccumulation of contaminants in key species, are very important since they can give us an idea about subsequent implications in higher trophic levels. Mysids may be important in the transfer of metals from the sediments and zooplankton to higher trophic levels such as fishes (e.g. Pomatoschistus microps and Liza ramada) (Delgado et al. 1997). According to Kestrup and Ricciardi (2008) $\mathrm{Hg}$ concentrations in fishes have been shown to be higher in lakes containing mysids than in mysid-free lakes. Therefore, regardless of the low $\mathrm{Hg}$ concentrations accumulated in mysids, it is hypothesized that they may constitute a vehicle of mercury transfer through the trophic web constituting a matter of concern for human health.

Acknowledgments This work was supported by FCT (Fundação para a Ciência e Tecnologia) through a project n. FCOMP-01-0124FEDER-010598 (MERCOAST, Ref ${ }^{\mathrm{a}}$. FCT PTDC/MAR/101906/ 2008) and by POPH and QREN-Promotion of scientific job funded by European social fund and national funds of MEC. The authors are indebted to all the colleagues that assisted in the field and lab work.

Conflict of interest The authors declare that they have no conflict of interest.

\section{References}

Azeiteiro UMM, Jesus L, Marques JC (1999) Distribution, population dynamics and production of the suprabenthic mysid Mesopodopsis slabberi van Beneden in the Mondego estuary (western coast of Portugal). J Crustacean Biol 19(3):498-509

Bignert A, Cossa D, Emmerson R, Fryer R, Füll C, Fumega J, Laane R, Calls HM, McHugh B, Miller B, Millward G, Moffat C, Pijnenburg J, Roose P, Ruus A, Schmolke S, Smedes F, Strand J,
Stronkhorst J, Thain J, Tissier C, Traas T, Tronczynski J (2004) OSPAR/ICES workshop on the evaluation and update of background reference concentrations (B/RCs) and ecotoxicological assessment criteria (EACs) and how these assessment tools should be used in assessing contaminants in water, sediments and biota. Final report to OSPAR Commission, The Hague, pp 92-96. Retrieved 20 October 2009 from http://www.ospar. org/documents/dbase/publications/p00214_BRC\%20EAC\%20 Workshop.pdf

Bu-Olayan AH, Mohammed HMA, Subrahmanyam MNV, Thomas BV (1998) Effect of size upon metal content of lobster (Thenus orientalis) from the Kuwait marine environment. Bull Environ Contam Toxicol 61:175-181

Cardoso PG, Brandão A, Pardal MA, Raffaelli D, Marques JC (2005) Resilience of Hydrobia ulvae populations to anthropogenic and natural disturbances. Mar Ecol Prog Ser 289:191-199

Cardoso PG, Sousa E, Matos P, Henriques B, Pereira E, Duarte AC, Pardal MA (2013) Impact of mercury contamination on the population dynamics of Peringia ulvae (Gastropoda): implications on metal transfer through the trophic web. Estuar Coast Shelf S. doi:10.1016/j.ecss.2013.06.002

Cockcroft AC, Webb P, Wooldridge T (1988) Nitrogen regeneration by two surf-zone mysids, Mesopodopsis slabberi and Gastrosaccus psammodytes. Mar Biol 99:75-82

Coelho JP, Pereira ME, Duarte A, Pardal MA (2005) Macroalgae response to a mercury contamination gradient in a temperate coastal lagoon (Ria de Aveiro, Portugal). Estuar Coast Shelf S 65:492-500

Coelho JP, Rosa M, Pereira E, Duarte A, Pardal MA (2006) Pattern and annual rates of Scrobicularia plana mercury bioaccumulation in a human induced mercury gradient (Ria de Aveiro, Portugal). Estuar Coast Shelf S 69:629-635

Coelho JP, Policarpo E, Pardal MA, Millward GE, Pereira ME, Duarte AC (2007) Mercury contamination in invertebrate biota in a temperate coastal lagoon (Ria de Aveiro, Portugual). Mar Pollut Bull 54:475-480

Council Directive 82/176/EEC on limit values and quality objectives for mercury discharges by the chlor-alkali electrolysis industry, 22 March 1982

Dauvin JC (1986) Dynamique de la population d'Abra prismatica (Mollusque, Bivalve) de la baie de Morlaix (manche occidentale). Ann I Oceanogr Paris 62(1):1-12

Delgado L, Guerao G, Ribera C (1997) Biology of the mysid Mesopodopsis slabberi (van Beneden, 1861) (Crustacea, Mysidacea) in a coastal lagoon of the Ebro delta (NW Mediterranean). Hydrobiologia 357:27-35

Drava G, Capelli R, Minganti V, Pellegrini RD, Relini LO, Ivaldi M (2004) Trace elements in the muscle of red shrimp Aristeus antennatus (Risso, 1816) from Ligurian Sea (NW Mediterranean): variations related to the reproductive cycle. Sci Total Environ 321:87-92

Elahi M, Esmaili-Sari A, Bahramifar N (2012) Total mercury levels in selected tissues of some marine Crustaceans from persian gulf, Iran: variations related to length, weight and sex. Bull Environ Contam Toxicol 88:60-64

Fanelli E, Cartes JE, Badalamenti F, Rumolo P, Sprovieri M (2009) Trophodynamics of suprabenthic fauna on coastal muddy bottoms of the southern Tyrrhenian sea (western mediterranean). J Sea Res 61:174-187

Fockedey N, Mees J (1999) Feeding of the hyperbenthic mysid Neomysis integer in the maximum turbidity zone of the Elbe, Westerschelde and Gironde estuaries. J Marine Syst 22:207228

Gayanilo FC, Pauly D (1997) FAO-ICLARM stock assessment tools (FISAT), reference manual. FAO computerized information series (Fisheries) No. 8, FAO, Rome, p 262 
Gentile SM, Gentile JH, Walker J, Heltshe JF (1982) Chronic effects of cadmium on two species of mysid shrimp: Mysidopsis bahia and Mysidopsis bigelowi. Hydrobiologia 93:195-204

González-Ortegón E, Drake P (2012) Effects of freshwater inputs on the lower trophic levels of a temperate estuary: physical, physiological or trophic forcing? Aquat Sci 74(3):455-469

Granda LD, Fockedey N, De Mey M, Beyst B, Cornejo MP, Calderon J, Vincx M (2004) Spatial patterns of the surf zone hyperbenthic fauna of Valdivia Bay (Ecuador). Hydrobiologia 529:205-224

Kennish MJ (2002) Environmental threats and environmental futures of estuaries. Environ Conserv 29(1):78-107

Kestrup ÅM, Ricciardi A (2008) Occurrence of the Ponto-Caspian mysid shrimp Hemimysis anomala (Crustacea, Mysida) in the St. Lawrence River. Aquat Invas 3:461-464

Laane RWPM (ed.) (1992) Background concentrations of natural compounds in rivers, sea water, atmosphere and mussels. Tidal waters division, Report DGW-92.033, pp 27-39

Lasenby DC, Van Duyn J (1992) Zinc and cadmium accumulation by the opossum shrimp Mysis relicta. Arch Environ Toxicol 23:179-183

Mason RP, Reinfelder JR, Morel MM (1995) Bioaccumulation of mercury and methylmercury. Water Air Soil Poll 80(1-4): 915-921

Minganti V, Capelli R, De Pellegrini R, Relini LO, Relini G (1996) Total and organic mercury concentrations in offshore crustaceans of the Ligurian sea and their relations to the trophic levels. Sci Total Environ 184:149-162

Mucci A, Lucotte M, Montgomery S, Plourde Y, Pichet P, Tra HV (1995) Mercury remobilization from flooded soils in a hydroelectric reservoir of northern Quebec, La Grande-2: results of a soil resuspension experiment. Can $\mathrm{J}$ Fish Aquat Sci 52:2507-2517

Nunes M, Coelho JP, Cardoso PG, Pereira ME, Duarte AC, Pardal MA (2008) The macrobenthic community along a mercury contamination in a temperate estuarine system (Ria de Aveiro, Portugal). Sci Total Environ 405:186-194

Pato P, Lopes C, Válega M, Lillebø AI, Dias JM, Pereira E, Duarte A (2008) Mercury fluxes between a coastal lagoon (Ria de Aveiro, Portugal) and the Atlantic ocean. Estuar Coast Shelf Sci 76:787-796
Pereira ME, Abreu SN, Coelho JP, Lopes CB, Pardal MA, Vale C, Duarte AC (2006) Seasonal fluctuations of tissue mercury contents in the European shore crab Carcinus maenas from low and high contaminations areas (Ria de Aveiro, Portugal). Mar Pollut Bull 52:1450-1457

Pereira ME, Lillebø AI, Pato P, Válega M, Coelho JP, Lopes CB, Rodrigues S, Cachada A, Otero M, Pardal MA, Duarte AC (2009) Mercury pollution in Ria de Aveiro (Portugal): a review of the system assessment. Environ Monit Assess 155:39-49

Pérez S, Beiras R (2010) The mysid Siriella armata as a model organism in marine ecotoxicology: comparative acute toxicity sensitivity with Daphnia magna. Ecotoxicology 19:196-206

Rappé K, Fockedey N, Van Colen C, Cattrijsse A, Mees J, Vincx M (2011) Spatial distribution and general population characteristics of mysid shrimps in the Westerschelde estuary (SW Netherlands). Estuar Coast Shelf 91:187-197

Remerie T, Bourgois T, Pealaers D, Vierstraete A, Vanfleteren J, Vanreusel A (2006) Phylogeographic patterns of the mysid $M$. slabberi (Crustacea, Mysida) in Western Europe: evidence for high molecular diversity and cryptic speciation. Mar Biol 149:465-481

Roast SD, Widdows J, Jones MB (2000) Mysids and trace metals: disruption of swimming as a behavioural indicator of environmental contamination. Mar Environ Res 50:107-112

Sardo AM, Morgado F, Soares AMVM (2005) Mesopodopsis slabberi (Crustacea: Mysidacea): can it be used in toxicity tests? Ecotox Environ Safe 60:81-86

Verslycke T, Vangheluwe M, Heijerick D, De Schamphelaere K, Van Sprang P, Janssen CR (2003) The toxicity of metal mixtures to the estuarine mysid Neomysis integer (Crustacea: Mysidacea) under changing salinity. Aquat Toxicol 64:307-315

Vilas C, Drake P, Pascual E (2009) Inter- and intra-specific differences in euryhalinity determine the spatial distribution of mysids in a temperate European estuary. J Exp Mar Biol Ecol 369:165-176

Webb P, Wooldridge TH (1990) Die1 horizontal migration of Mesopodopsis slabberi (Crustacea: Mysidacea) in Algoa Bay, southern Africa. Mar Ecol Prog Ser 62:73-77

Zar J (1996) Biostatistical Analysis, 3rd edn. Prentice-Hall, Upper Saddle River 